\title{
MEDICINAL EFFECT REVIEW OF AGARWOOD LEAVES FROM AQUILARIA AND GYRINOPS GENERA
}

\author{
Oleh \\ I Gde Adi Suryawan Wangiyana \\ Program Studi Kehutanan Universitas Pendidikan Mandalika \\ dede.consultant@gmail.com
}

\begin{abstract}
Abstrak
Aquilaria and Gyrinops are the most common genera of Agarwood in Indonesia. These two group have wide distribution in Indonesia. Therefore, Indonesia is one of the biggest agarwood commodity producer in the world. However, the resin on agarwood stem is still main utilization of agarwood commodity in this country. Diversification agarwood utilization other than resin is needed to maximilize the potency of this commodity. Agarwood leaves are one of by product from agarwood cultivation that rarely been utilized. Agarwood leaves contain secondary metabolites that have medical effect such as Phenol, Flavonoid, Terpenoid, Alkaloid and Tannin. Thus, agarwood leaves has a good potency as a source of food and beverage product that have a medicinal effects. Agarwood leaves form Aquilaria group and Gyrinops group both have medicinal effect including antioxidant, antibacterial, cytotoxic and anticancer. Aquilaria leaves also has additional medicinal effect including: anti-inflammatory, anti-diabetic and laxative while Gyrinops leaves also has additional medicinal effect as antiradical source of sunscreen.
\end{abstract}

Keyword: Medicinal Effect, Aquilaria, Gyrinops

\section{PENDAHULUAN}

Gaharu adalah hasil hutan bukan kayu bernilai ekonomis tinggi yang dihasilkan terutama oleh Famili Thymeleaceae, khususnya genus Gyrinops dan Aquilaria (López-Sampson \& Page, 2018). Indonesia sendiri merupakan salah satu negara penghasil gaharu terbesar di dunia. Karena memiliki sebaran tanaman pengahsil gaharu dari genus Aquilari maupun Gyrinops yang tersebar di hampir semua wilayahnya (Turjaman and Hidayat, 2017). Kelompok genus Aquilaria cenderung terdistribusi di wilayah barat Indonesia, sementara itu kelompok genus Gyrinops cenderung terdistribusi di wilayah timur Indonesia (Roemantyo \& Partomihardjo, 2010)

Resin gaharu yang dikenal dengan istilah "gubal" merupakan produk dominan komoditi gaharu yang beredar di pasar Internasional (Naziz et al., 2019). Nilai jual yang tinggi dari produk gubal ini menyebabkannya menjadi primadona sekaligus komoditi internasional kelas atas (Siran, 2014). Selain itu, gubal gaharu dapat diolah menjadi berbagai produk industry berbasis aromaterapik diantaranya: sahampoo, sabun, parfum dan minyak atsiri (Turjaman, 2014) Negara - negara di Timur Tengah merupakan negara dominan yang memagang pasar internasional dari komoditi resin gaharu ini (Antonopoulou et al., 2010)

Terlalu dominannya pemanfaatan resin dari organ batang pohon gaharu menyebabkan kurangnya diversifikasi komoditi gaharu. Padahal pemanfaatan dominan resin gaharu pada batang mempunyai beberapa kelemahan. Produksi resin gaharu terutama dari gaharu budidaya membutuhkan proses yang dikenal dengan induksi induksi (Tan et al., 2019). Metode induksi ini sampai saat ini terus mengalami perkembangan dan menjadi faktor kunci produksi resin (Wangiyana, 2020). Dengan demikian dapat dikatakan bahwa pohon gaharu yang tidak mendapatkan perlakuan induksi, tidak akan menghasilkan resin (Azren et al., 2019) sehingga proses ini membutuhkan perhatian khusus oleh petani gaharu (Wangiyana et al., 2020). Permasalahan timbul dikalangan petani gaharu terkait waktu investasi yang cukup lama dari proses induksi tersebut yang membutuhkan waktu investasi minimal 12 tahun sejak masa semai (Akter et al., 2013). Selama masa tunggu investasi tersebut, petani gaharu membutuhkan pemanfaatan alternatif komoditi gaharu selain resin, salah satunya adalah organ daun (Wangiyana \& Sami’un, 2018) 
Daun gaharu umumnya merupakan limbah dari kegiatan pruning yang umum dilakukan dalam budidaya gaharu (Wangiyana \& Putri, 2019a). Disatu sisi, daun gaharu dapat diolah menjadi produk bernilai ekonomi yaitu minuman herbal (Wangiyana et al., 2019). Pembuatan produk minuman herbal tersebut dapat dilakukan baik menggunakan daun gaharu kelompok genus Gyirinops (Wangiyana \& Putri, 2019b) maupun Aquilaria (Karsiningsih, 2016).

Pemanfaatan daun gaharu sebagai komoditi alternatif dari resin gaharu dalam rangka diversifikasi produk perlu lebih di populerkan sehingga lebih dikenal luas baik dikalangan akademisi maupun petani gaharu (Wangiyana, et al., 2019). Selama ini produk resin gaharu dalam bentuk olahan berupa minyak esensial populer dengan khasiat medisnya (Wangiyana, 2019). Daun gaharu sendiri berdasarkan beberapa penelitian terbukti memiliki khasiat medis baik yang berasal dari genus Aquilaria (Wahid \& Ittiqo, 2019) maupun Gyrinops (Wangiyana et al., 2020). Oleh karena itu, artikel review ini bertujuan untuk memamparkan secara detail khasiat medis daun gaharu Genus Aquilaria maupun Gyrinops dalam rangka menggalakkan diversifikasi produk komoditi gaharu.

\section{FITOKIMIA DAUN GAHARU}

Secara Farmakologi daun gaharu memiliki kelompok senyawa yang memiliki potensi khasiat medis. Kandungan senyawa pada daun gaharu ditentukan oleh metode yang digunakan untuk melakukan analisis. Namun kelompok senyawa yang ditemukan tidak berbeda signifikan (Adam et al., 2017).

Daun gaharu kelompok genus Aquilaria mengandung komponen kelompok senyawa 2(Phenylethyl) chromones yang merupakan senyawa umum ditemukan juga pada resin gaharu. Turunan dari kelompok senyawa ini diantaranya adalah 5-hydroxy-6methoxy-2-(2phenylethyl) chromone, 6-methoxy-2-[2-2(3methoxy-4-hydroxypenyl)ethyl] chromone dan 6hydroxy-2-2[2-(hydroxyphenyl) ethyl] chromone (Wang et al., 2015)

Daun gaharu Aquilaria juga mengandung kelompok senyawa Fenol yang merupakan kelompok senyawa umum ditemukan pada organ daun. Beberapa anggota kelompok senyawa fenol pada daun Aquilaria diantaranya Vanilic acid, Isovanilic acid, Methylparaben dan Syringic acid. Senyawa -senyawa tersebut merupakan metabolit sekunder yang ditemukan pada Aquilaria sinensis (Kang et al., 2014).

Kelompok senyawa fitosterol juga ditemukan pada daun kelompok genus Aquilaria. Salah satu anggota kelompok fitosterol penting yang ditemukan pada daun Aquilaria sinensis adalah ergosterol. Hal ini merupakan suatu hal yang unik karena ergosterol sendiri merupakan kompoen senyawa yang umum dijumpai pada kelompok Fungi (Yang et al., 2014)

Daun Aquilaria juga mengandung serangkaian kelompok senyawa kompleks yang terdiri dari beberapa gugus fungsi berbeda. Kelmpok senyawa dominan adalah asam lemak yang terdiri dari: 1,2,3 - propanteriol monoacetate, 9,12,15- octadecaterineoic acid, Dodecyl acrylate dan 1-Tetradecanol. Selain itu terdapat juga kelompok senyawa Pyranones, Quinones dan beberapa senyawa karbohidrat yang terkonjugasi (Khalil et al., 2013)

Kelompok senywa terbesar yang dapat ditemukan pada daun gaharu genus Aquilaria adalah Flavonoid. Senyawa genkwanin merupakan golongan flavonoid yang paling banyak dilaporkan terdapat pada daun Aquilaria berdasarkan hasil penelitian dan menjadi salah satu senywa ciri khas dari daun gaharu (Wang., 2008, Ito et al., 2012, Yu et al., 2013 Qi et al., 2009). Selain itu terdapat pula senywa flavonoid Apigenin (Ariffin et al., 2013), Luteolin (Yu et al., 2013) turunan senyawa Luteolin dan dimethoxyflavone (Kang et al., 2014), Epicatechin gallate dan Epigallocatechin gallate (Tay et al., 2014) dan Vitexin (Sun et al., 2105).

Beberapa senyawa tambahan yang khas juga ditemukan pada analisis fitokimia daun gaharu. Beberapa diantaranya adalah cucurbitacin (Feng et al., 2011), Friedelan-3-one (Wei and Bin, 2011) yang tergolong senyawa terpenoid, kelompok senyawa Nukelosida (Wang et al., 2015), kelompok senyawa Alkanes (Wei and Bin, 2011), senyawa alkaloid dari jenis Isocorydine (Nie et al., 2009) serta vitamin $\mathrm{E}$ (Xia et al., 2013)

Penelitian fitokimia daun gaharu Genus Gyrinops tidak sebanyak dan seintesif penelitian fitokimia daun gaharu Genus Aquilaria. Hal ini menyebabkan penelitian fitokimia terhadap daun gaharu Gyrinops perlu ditingkatkan (Wangiyana et al., 2018). Data studi fitokimia tersebut dapat dijadikan sebagai dasar yang kuat untuk mengembangkan produk berbasis daun gaharu di level industri terutama yang melibatkan 
kombinasi dengan berbagai bahan herbal lainnya (Wangiyana, et al., 2019)

Skrining awal terhadap ekstrak daun Gyrinops menunjukkan bahwa senyawa yang terkandung didalamnya tidak jauh berbeda dengan senyawa yang terdapat dalam daun Aquilaria. Berdasarkan hasil Fraksinasi senyawa dengan metode kromatografi lapis tipis, ekstrak ini mengandung komponen kelompok senyawa Phenolic, Flavonoid, Tannin dan Terpenoid (Nuringtyas et al., 2018)

\section{KHASIAT MEDIS DAUN AQUILARIA}

Daun gaharu dari kelompok Aquilaria telah secara intesif diteliti khasiat medisnya karena merupakan salah satu bahan obat tradisional. Penelitian terkait khasiat medis ini berguna untuk pengembangan produk - produk yang dikembangkan dari bahan baku daun Aquilaria, salah satunya adalah minuman herbal (Adam et al., 2017)

Daun gaharu secara fitokimia banyak mengandung senyawa - senyawa yang memiliki potensi antioxidant. Daun Aquilaria sinensis mengandung kelompok senyawa Flavonoid yang terbukti mempunyai aktivitas antioksidan melalui uji DPPH dan ABTS (Duan et al., 2015). Daun gaharu A. malaccemsis mengandung kelompok senyawa Flavonoid dan polifenol yang memiliki aktivitas antioksidan kuat (Harahap et al., 2015). Aktivitas antioksidan dari daun A. malaccensis tersebut ditentukan oleh pelarut yang digunakan untuk melakukan ekstraksi (Hendra et al., 2016)

Daun gaharu Aquilaria memiliki aktivitas antimicrobial yang mampu menghambat pertumbuhan mikroorganisme meliputi bakteri dan jamur. Ekstrak daun A. sinensis terbukti memiliki aktivitas antibakteri terhadap Staphylococcus epidermidis yang merupakan penyebab infeksi pada kulit (Kamonwannasit et al., 2013). Selain itu ekstrak ini juga mampu menghambat pertumbuhan bakteri urease positif Staphylococcus aureus, Clostridium difficile dan kelompok Bacteriodes (Kakino et al., 2012). Ekstrak daun A. agallocha dilaporkan bersifat antibakteri terhadap Shigella flexeneri, Bacillus brevis, Pseudomonas aeruginosa dan Bacillus subtilis (Dash et al., 2008). Ekstrak etanol daun A. microcarpa memiliki aktivitas antibakteri terhadap Staphylococcus aureus dan Proteus mirabilis (Sari et al., 2017) .Selain menghambat pertumbuhan bakteri, daun Aquilaria agallocha mengandung senyawa cucrbitacins yang memiliki potensi antifungal (Chen et al., 2014).
Ekstrak daun gaharu memiliki khasiat dalam mengatur kadar gula dalam darah. Hal ini menunjukkan potensinya sebagai agen antidiabetes (Zulkifle, 2018). Ekstrak etanol Aquilaria sinensis memiliki efek hypoglycemic

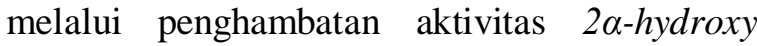
ursolic acid (Mei et al., 2013). Sebagai tambahan, ekstrak metanol dan ekstrak air daun A. sinensis mampu meningkatkan penyerapan glukosa pada jaringan adipose sebagaimana layaknya kerja dari enzim insulin sehingga berpotensi sebagai agen antihyperglicemic (Pranakhon et al., 2011)

Daun gaharu kelompok Aquilaria secara medis memiliki khasiat meredakan rasa nyeri secara umum. Daun A. sinensis dilaporkan memiliki aktivitas anti-inflammatory dan antinocieptive (Zhou et al., 2008). Salah satu senyawa yang berperan sebagai antiinflammatory pada daun $A$. sinensis adalah friedelan-3-one (Wei \& Bin, 2011). Sebagai tambahan, ekstrak etanol dari daun A. agallocha memiliki potensi sebagai agent senyawa antiarthritic (Rahman et al., 2016)

Daun gaharu kelompok Aquilaria memiliki potensi untuk melawan sel - sel kanker. Pada ekstrak daun Aquilaria malaccensis terdapat beberapa senyawa yang memiliki potensi anti kaner diantaranya: 9- hexadecanoic acid, tetracosanoic acid, calarene, 2,6-octadien-1-ol, 3,7-dimethyl, 3,6-octadecadiynoic acid, 3octadecyne, lauric acid, myristic acid, nonadecanoic acid, oleic acid, phytol, loliolide, dan squalene (Millaty et al., 2020)

Daun gaharu kelompok Aquilaria dapat mempengaruhi aktivitas kontraksi usus. Daun $A$. sinensis yang diolah dalam bentuk teh terbukti dapat meningkatkan kontraksi usus halus (Li et al., 2013). Dengan demikian, dapat dikatakan bahwa daun A. sinensis memiliki aktivitas laksatif. Sifat laksatif tersebut tanpa memberikan efek samping berupa gejala diare (Hara et al., 2008). Senyawa Mangiferin dan Genkwanin yang ditemukan pada ekstrak daun $A$. sinensis merupakan senyawa yang bertanggung jawab terhadap efek laksatif tersebut (Kakino \& Hara, 2016). Senyawa tersebut mampu merangsang kontraksi usus halus untuk meringankan gejala konstipasi (Kakino et al., 2010).

\section{KHASIAT MEDIS DAUN GYRINOPS}

Penelitian terkait khasiat medis daun Gyrinops tidak sebanyak penelitian khasiat medis daun Aquilaria. Akan tetapi karena secara fitokimia, kandungan senyawa daun Gyrinops 
kurang lebih sama dengan kandungan senyawa daun Aquilaria sehingga dapat diprediksi bahwa daun Gyrinops juga memiliki khasiat medis yang sama dengan daun Aquilaria. (Hendra et al., 2016)

Daun Gyrinops versteegii merupakan sumber senyawa antioksidan yang potensial. Berdasarkan hasil uji antioksidan dengan berbagai metode yaitu: DPPH radicals scavenging activity, reducing power dan $\beta$ carotene bleaching assay diperoleh hasil bahwa daun $G$. versteegii mempunyai aktivitas antioksidan lebih baik dibandingkan kulit batang dan kulit buah. Hal ini mengindikasikan bahwa daun gaharu merupakan bahan baku yang layak dikembangkan sebagai sumber antioksidan (Prihantini \& Rizqiani, 2019)

Dua kelompok senyawa yang bertanggung jawab terhadap aktivitas antioksidan dari daun G. versteegii adalah Fenol dan Flavonoid. Kedua senyawa tersebut memang merupakan senyawa yang umum dijumpai pada bahan alam yang memiliki aktivitas antioksidan. Ekstrak air daun G. versteegii mengandung total senyawa fenol sebesar 14,98 mg/ $100 \mathrm{mg}$ (Parwata et al., 2016). Sementara itu ekstrak air daun G. versteegii juga mengandung kelompok senyawa flavonoid jenis 5-hydroxy-flavonol dengan total konsentrasi sebesar 2298,977 mg QE/100 gram (Parwata et al., 2018).

Selain memiliki kandungan Fenol dan Flavonoid, daun G. versteegii juga dilaporkan mengandung senyawa terpenoid yang memiliki aktivitas antioksidan. Pengujian kemampuan antioksidan dilakukan dengan pengukuran aktivitas antiradical bebas terhadap ekstrak metanol daun $G$. versteegii. Hal ini juga mengindikasikan potensi daun $G$. versteegii sebagai bahan obat tradisional atau yang dikenal juga dengan "etnomedicine" (Mega \& Swastini, 2012)

Kemampuan daun G. versteegii dalam mencegah reaksi radikal bebas membuatnya berpotensi digunakan untuk melindungi kulit dari radikal bebas yang disebabkan oleh UV pada sinar matahari. Kemampuan ini menyebabkan ekstrak daun $G$. versteegii dapat digunakan sebagai tabir surya. Kemampuan tabir surya dari ekstrak $G$. versteegii diuji dengan mengukur nilai Sun Protection Factor (SPF). Ekstrak metanol daun G. versteegii terbukti memiliki aktivitas tabir surya tergolong ultra (Nilai SPF > 15) dan lebih besar dibandingkan dengan ekstrak etil asetat dan n-heksana (Wahyuningrum et al., 2018).

Aktivitas antioksidan daun $G$ versteegii juga berkorelasi dengan aktivitas cytotoxic. Ekstrak kloroform daun G. versteegii terbukti memiliki aktivitas cytotoxic terhadap HeLA cell line dengan nilai IC50 sebesar 22,71 $\pm 1,31 \mu \mathrm{g}$ $\mathrm{mL}^{-1}$. Fraksinasi lebih lanjut terhadap senyawa yang memiliki aktivitas cytotoxic dengan menggunakan metode kromatografi lapis tipis menunjukkan bahwa fraksi tersebut mengandung senyawa Fenol, Flavonoid dan Terpen. (Nuringtyas et al., 2018)

Aktivitas cytotoxic dari daun G. versteegii berkorelasi dengan kemampuannya sebagai bahan baku senyawa antikanker. Ekstrak kloroform daun $G$. versteegii terbukti memiliki kemampuan mencegah metastasis terhadap cell line kanker payudara T47D. Ekstrak tersebut dapat menghambat terjadinya migrasi dan agregasi sel kanker T47D mulai dari konsentrasi 1/8 IC50 yaitu sebesar 19,105 $\mu \mathrm{g} / \mathrm{mL}$ untuk daun $G$. versteegii asal Bogor dan 23,0562 $\mu \mathrm{g} / \mathrm{mL}$ untuk daun $G$. versteegii asal Kota Mataram (Septia, 2019).

Daun G. versteegii dilaporkan juga memiliki aktivitas antibakteri. Aktivitas antibakteri ini setara dengan aktivitas antibakteri resin gaharu yang selama ini umum dikenal sebagai sumber senyawa antibakteri. Ekstrak etanol dan ekstrak metanol daun $G$. versteegii terbukti mampu menghambat pertumbuhan bakteri uji Staphylococcus aureus ATCC25923 (Wangiyana et al., 2020)

\section{KESIMPULAN}

Daun gaharu memiliki banyak khasiat medis yang menjadikannya bahan baku potensial untuk produk kesehatan. Secara umum daun gaharu kelompok Gyrinops dan Aquilaria memiliki potensi antioksidan, antibacterial, cytotoxic dan antikanker. Daun Aquilaria memiliki khasiat anti-inflammatory, antidiabetic, dan laksatif yang belum diuji pada daun Gyrinops. Sementara itu daun Gyrinops mempunyai khasiat tabir surya yang belum diujikan pada daun Aquilaria.

\section{SARAN}

Daun gaharu kelompok Aquilaria dan Gyrinops hanya berbeda secara morfologi, sementara dari segi fitokimia kandungan senyawa keduanya relatif sama. Oleh karena itu 
diperlukan penelitian yang mengkaji aktivitas khasiat medis daun gaharu Aquilaria yang belum di uji pada daun gaharu Gyrinops begitu pula sebaliknya sehingga lebih mendetailkan khasiat medis dari daun gaharu secara umum.

\section{DAFTAR PUSTAKA}

Adam, A. Z., Lee, S. Y., \& Mohamed, R., 2017. Pharmacological properties of agarwood tea derived from Aquilaria (Thymelaeaceae) leaves: An emerging contemporary herbal drink. Journal of Herbal Medicine, 10(2017), 37-44. https://doi.org/10.1016/j.hermed.2017.06.0 02

Akter, S., Islam, M. T., Zulkefeli, M., \& Khan, S. I., 2013. Agarwood Production - A Multidisciplinary Field to be Explored in Bangladesh. International Journal of Pharmaceutical and Life Sciences, 2(1), 22-32. https://doi.org/10.3329/ijpls.v2i1. 15132

Antonopoulou, M., Compton, J., Perry, L. S., \& Al-Mubarak, R., 2010. the Trade and Use of Agarwood (Oudh) in the United Arab Emirates. https://www.trafficj.org/public ation/10_Trade_Use_Agarwood. (Diakses: 2 Juni 2020)

Arrififin, N. M., Alimon, H., Sukari, M. A., Naz, H., 2013. Chemical study of Aquilaria crassna. Chem. Nat. Compd. 49, 575 - 576.

Azren, P. D., Lee, S. Y., Emang, D., \& Mohamed, R., 2019. History and Perspectives of Induction Technology for Agarwood Production from Cultivated Aquilaria in Asia: A Review. Journal of Forestry Research, 30(1), 1-11. https://doi.org/10.1007/s11676-018-0627-4

Chen, C. H., Kuo, T. C. Y., Yang, M. H., Chien, T. Y., Chu, M. J., Huang, L. C., Chen, C. Y., Lo, H. F., Jeng, S. T., Chen, L. F. O., 2014. Identification of cucurbitacins and assembly of a draft genome for Aquilaria agallocha. BMC Genomics, 15, 1 - 11.

Dash, M., Patra, J. K., Panda, P. P., 2008. Phytochemical and antimicrobial screening of extracts of Aquilaria agallocha Roxb. African Journal of Biotechnology. 7 (20), 3531 - 3534.

Duan, Z., Li, W., Dou, Z., Xie, H., He, A., Shi, M., 2015. Extraction and antioxidant activity of flavonoids from Aquilaria sinensis (Lour) Gilg leaves. J. Food Sci. 36, $45-50$.

Feng, J., Yang, X. W., Wang, R. F., 2011. Bioassay guided isolation and identification of $\alpha$-glucosidase inhibitor from leaves of Aquilaria sinensis. Phytochmistry, 72, 242 $-247$.

Hara, H., Ise, Y., Morimoto, N., Shimazawa, M., Ichihashi, K., Ohyama, M., \& Iinuma, M., 2008. Laxative Effect of Agarwood Leaves and Its Mechanism. Bioscience, Biotechnology, and Biochemistry, 72(2), 335-345. https://doi.org/10.1271/bbb. 70361

Harahap, R. K., Batubara, R., \& Surjanto., 2015. Uji Antioksidan Daun Muda dan Daun Tua Gaharu (Aquilaria malaccensis Lamk) Berdasarkan Perbedaan Tempat Tumbuh Pohon. Peronema Forestry Science Journal, 4 (4), 72-87.

Hendra, H., Moeljopawiro, S., \& Nuringtyas, T. R., 2016. Antioxidant and antibacterial activities of agarwood (Aquilaria malaccensis Lamk.) leaves. AIP Conference Proceedings, 1755(14004). https://doi.org/10.1063/1.4958565

Ito, T., Kakino, M., Tazawa, S., Oyama, M., Maruyama, H., Araki, Y., Hara, H., Linuma, M., 2012. Identification of phenolic compounds in Aquilaria crassna leaves via liquid chromatographyelectrospray ionization mass spectroscopy. Food Sci. Technol. Res., 18, 259 - 262.

Kakino, M., Hara, H., 2016. Pharmacological effects of Aquilaria spp. Leaves and their chemical constituents. In: Mohamed, R. (Ed.), Agarwood. Springer, Singapore, pp. $125-136$.

Kakino, M., Sugiyama, T., Kunieda, H., Tazawa, S., Maruyama, H., 2012. Agarwood (Aquilaria crassna) extracts decrease high-protein highfat diet-induced intenstinal putrefaction toxins in mice. Pharm. Anal. Acta, 3: 152.

Kakino, M., Tazawa, S., Maruyama, H., Tsuruma, K., Araki, Y. Shimazawa, M., Hara, H., 2010. Laxative effects of agarwood on low-fiber diet-induced constipation in rats. BMC Complement. Altern. Med. 10, 1 - 8 .

Kamonwannasit, S., Nantapong, N., Kumkrai, P., Luecha, P., Kupittayanant, S., \& Chudapongse, N., 2013. Antibacterial activity of Aquilaria crassna leaf extract against Staphylococcus epidermidis by 
disruption of cell wall. Annals of Clinical Microbiology and Antimicrobials, 12(1), 1. https://doi.org/10.1186/1476-0711-12-20

Kang, Y. F., Chien, S. L., Wu, H. M., Li, W. J., Chen, C. T., Li, H. T., Chen, H. L., Chao, D., Chen, S. J., Huang, C. T., Chen, C. Y., 2014. Sceondary metabolites from the leaves of Aquilaria sinensis. Chem. Nat. Compd. 50, 1110 - 1112.

Karsiningsih, E., 2016. Analisis Kelayakan Finansial dan Strategi Pengembangan Teh Gaharu di Kabupaten Bangka Tengah (Studi Kasus: Teh Gaharu "Aqilla" Gapoktan Alam Jaya Lestari). AGRARIS: Journal of Agribusiness and Rural Development Research, 2(2), 143-151. https://doi.org/10.18196/agr.2235

Khalil, A. S., Rahim, A. A., Taha, K. K., Abdallah, K. B., 2013. Characterization of methanolic extracts of agarwood leaves. $J$. App. Ind. Sci. 1, 78 -88.

Li, H., Jiang, Z., Mei, Q., 2013. Comparative study on the effect of Aquilaria sinensis leaf tea and agarwood on promoting small intestine propulsion. Asia-Pasific Tradit. Med. 9, 24-25

López-Sampson, A., \& Page, T., 2018. History of Use and Trade of Agarwood. Economic Botany, 72(1), 107-129. https://doi.org/ 10.1007/s12231-018-9408-4

Mega, I., \& Swastini, D., 2012. Screening Fitokimia Dan Aktivitas Antiradikal Bebas Ekstrak Metanol Daun Gaharu (Gyrinops versteegii). Jurnal Kimia, 4(2), 187-192.

Mei, Q., Li, H., Lin, H., Wu, X., Liang, L., Yang, H., Lan, Z., 2013. Comparative study on hypoglycemic effect between Aquilaria sinensis leaves and agarwood. Lishizhen Med. Mat. Med. Res. 24, 1606 - 1607.

Millaty, I. N. K., Wijayanti, N., Hidayati, L., \& Nuringtyas, T. R., 2020. Identification of anticancer compounds in leaves extracts of agarwood ( Aquilaria malaccensis ( Lamk .)). IOP Conf. Series: Earth and Environmental Science, 1-8. https://doi.org/10.1088/17551315/457/1/012036

Naziz, P. S., Das, R., \& Sen, S., 2019. The scent of stress: Evidence from the unique fragrance of agarwood. Frontiers in Plant Science, $10(840)$, 1-13. https://doi.org/10.3389/fpls.2019.00840

Nie, C., Song, Y., Chen, D., Xue, P., Tu. P., Wang, K. Chen, J. 2009. Studies on chemical constituents of leaves of Aquilaria sinensis. China J. Chin. Mater. Med., 34, $858-860$

Nuringtyas, T. R., Isromarina, R., Septia, Y., Hidayati, L., Wijayanti, N., \& Moeljopawiro, S., 2018. The antioxidant and cytotoxic activities of the chloroform extract of agarwood (Gyrinops versteegii (Gilg.) Domke) leaves on HeLa cell lines. AIP Conference Proceedings, 2002(020067), 1-9. https://doi.org/10.1063 $/ 1.5050163$

Parwata, A, Manuba, P., Yasa, S., \& Bidura, I. G. N. G., 2016. Characteristics and Antioxidant Activities of Gaharu (Gyrinops versteegii) Leaves. Journal of Biological and Chemical Research, 33(1), 294-301.

Parwata, Adi, Manuaba, P., \& Yasa, S., 2018. The potency of flavonoid compounds in water extract Gyrinops versteegii leaves as natural antioxidants sources. Biomedical and Pharmacology Journal, 11(3), 15011511. https://doi.org/10.13005/bpj/1517

Pranakhon, R., Pannangpetch, P., \& Aromdee, C., 2011. Antihyperglycemic activity of agarwood leaf extracts in STZ-induced diabetic rats and glucose uptake enhancement activity in rat adipocytes rats and glucose uptake enhancement activity in rat adipocytes. Songklanakarin J. Sci. Technol., 33(4), 405-410.

Prihantini, A. I., \& Rizqiani, K. D., 2019. Various antioxidant assays of agarwood extracts (Gyrinops versteegii) from West Lombok, West Nusa Tenggara, Indonesia. Asian Journal of Agriculture, 3(1), 1-5. https://doi.org/10.13057/asianjagric/g0310 1

Qi, J., Lu, J. J., Liu, J. H., Yu, B.Y., 2009. Flavonoid and a rare benxophenone glycoside from the leaves of Aquilaria sinensis. Chem. Pharm. Bull. 57, 134 - 137.

Rahman, H., Eswaraiah, M. C., Dutta, A. M., 2016. Anti-arthritic activity of leaves and oil of Aquilaria agallocha. Saudi J. Life Sci. 1, $34-43$.

Roemantyo, \& Partomihardjo, T., 2010. Analisis Prediksi Sebaran Alami Gaharu Marga Aquilaria dan Gyrinops di Indonesia. Berita Biologi, 10(2), 189-198.

Sari, R., Mutiara, M., Fakriaty, I., 2017. Uji aktivitas antibakteri ekstrak etanol daun gaharu (Aquilaria microcarpa Bail.) 
terhadap bakteri Staphylococcus aureus dan Proteus mirabilis. Pharm. Sci. Res. 4 (3), $143-154$

Septia, Y., 2019. Antimetastasis ekstrak kloroform daun gaharu (Gyrinops versteegii (Gilg.) Domke) terhadap cell line kanker payudara T47D. Skripsi. Universitas Gadjah Mada. Yogyakarta

Siran, S. A., 2014. Gaharu Bioinduksi: Komoditi Elit Masa Depat Sektor Kehutanan. In A. Susmianto, M. Turjaman, \& P. Setio (Eds.), Rekam Jejak Gaharu Inokulasi (2nd ed., pp. 17-32). FORDA Press.

Sun, J., Xia, F., Wang, S., Wang, K. Y., Chen, J. M., Tu, P. F., 2015. Structural elucidation of two new megastigmane glycosides from the leaves of Aquilaria sinensis. Chin. J. Nat. Med. 13, 0290 - 0294

Tan, C. S., Isa, N., Ismail, I., \& Zainal, Z., 2019. Agarwood Induction: Current Developments and Future Perspectives. Frontiers in Plant Science, 10 (122), 1-13. https://doi.org/10.3389/fpls.2019.00122

Tay, P. Y., Tan, C. P., Abas, F., Yim, H. S., Ho, C. W., 2014. Assessment of extraction parameters on antioxidant capacity, polyphenol content, epigallocatechin gallate (EGGG), epicatechin gallate (ECG) and iriflophenone 3-C- $\beta$-glucoside of agarwood (Aquilaria crassna) young leaves. Molecule, 19, 12304 - 12319

Turjaman, M. \& Hidayat, A., 2017. Agarwoodplanted Tree Inventory in Indonesia. In: IOP Conference Series: Earth and Environmental Sciece. https://doi.org/ 10.1088/17551315/54/1/012062

Turjaman, M., 2014. Industri Hulu-Hilir Gaharu. In A. Susmianto, M. Turjaman, \& P. Setio (Eds.), Rekam Jejak Gaharu Inokulasi (2nd ed., pp. 185-216). FORDA Press.

Wahid, A. R., \& Ittiqo, D. H., 2019. Daya Hambat Bakteri Staphylococcus aureus Ekstrak Daun Gaharu (Aquilaria malea L.) Sebagai Antibakteri. Jurnal Insan Farmasi Indonesia, 2(1), 34-43. https://doi.org/ 10.1017/CBO9781107415324.004

Wahyuningrum, M., Sari, R. K., \& Rafi, M., 2018. Aktivitas Antioksidan dan Tabir Surya Ekstrak Daun Gyrinops versteegii. Jurnal Ilmu Teknologi Kayu Tropis, 16(2), 141-149.

Wang, H., 2008. Determination of Genkwanin in the leaves of Aquilaria sinensis (Lour) Gilg. With HPCL. J Trad. Chin. Med. Pharm. 14, $69-70$
Wang, H., Zhou, M., Lu, J., Yu, B., 2008. Antitumor constituent from leaves of Aquilaria sinensis (Lour) Gilg. Linchan Huazue Yu Gongye, 28, 1 - 5

Wang, S. C., Wang, F., Yue, C. H., 2015. Chemical constituent form the petiole and leaves of Aquilaria sinensis. Biochem. Syst. Ecol. 61, 458-461.

Wang, S. C., Wang, F., Yue, C. H., 2015. Chemical constituents from the petioles and leaves of Aquilaria sinensis. Biochem. Syst. Ecol, $61-458-461$

Wangiyana, I. G. A. S., 2019. Medicinal Usage of Agarwood Resin in Form of Essential Oil: A Review. Jurnal Silva Samalas, 2(2), 86-90.

Wangiyana, I. G. A. S., 2020. Development of Agarwood Induction Technology on Agarwood Cultivation-A Review. Jurnal Sangkareang Mataram, 6(1), 29-38.

Wangiyana, I. G. A. S., Isbulloh, F., \& Akram., 2020. Perbandingan Aktivitas Antibakteri Ekstrak Kasar Resin dan Daun Gaharu (Gyrinops versteegii). Jurnal Bioteknologi \& Biosains Indonesia, 7(1), 28-36.

Wangiyana, I. G. A. S., \& Putri, D. S., 2019a. Aplikasi Zat Pengatur Tumbuh dan Kegiatan Pruning Dalam Optimalisasi Budidaya Gaharu Di Desa Duman Kecamatan Lingsar Lombok Barat. Lumbung Inovasi, 4(1), 1-7.

Wangiyana, I. G. A. S., \& Putri, D. S., 2019b. Teh Gyrinops: Produk Inovatif dari Istri Petani Desa Duman Kecamatan Lingsar Kabupaten Lombok Barat. Prosiding PEPADU, 1(1), 388-396.

Wangiyana, I. G. A. S., Putri, D. S., \& Triandini, I. G. A. A. H., 2019. Pelatihan Pengolahan Daun Gaharu Menjadi Teh Herbal Untuk Istri Petani Anggota Kelompok Tani Desa Duman. Logista Jurnal Ilmiah Pengabdian Kepada Masyarakat, 3(2), 82-89.

Wangiyana, I. G. A. S., \& Sami'un., 2018. Characteristic of Agarwood Tea from Gyrinops versteegii Fresh and Dry Leaves. Sangkareang, 4(2).

Wangiyana, I. G. A. S., Sawaludin, Nizar, W. Y., \& Wangiyana, W., 2019. Tannin concentrations of Gyrinops tea with different leaf processing methods and addition of herbal medicine ingredients Tannin Concentrations of Gyrinops Tea with Different Leaf Processing Methods and Addition of Herbal Medicine Ingredients. AIP Conference Proceedings, 
2199(070012), 1-7.

Wangiyana, I. G. A. S., Triandini, I. G. A. A. H., Putradi, D., \& Wangiyana, W., 2018. Tannin Concentration of Gyrinops Tea from Leaves of Juvenile and Mature Agarwood Trees ( Gyrinops versteegii Gilg ( Domke )) with Different Processing Methods. Journal of Chemical and Pharmaceutical Research, 10(10), 113119.

Wangiyana, I. G. A. S., Wanitaningsih, S. K., \& Anggadhania, L., 2020. Pelatihan Teknologi Bio-induksi untuk Petani Gaharu di Desa Pejaring Kabupaten Lombok Timur. Agrokreatif Jurnal Ilmiah Pengabdian Kepada Masyarakat, 6(1), 3644.

Wangiyana, I. G. A. S., Malik, S., 2018. Application of Arbuscular Mycorrhiza from Senaru Forest Rhizosphere for Gyrinops versteegii Germination and Growth. Biosaintifika, 10 (2), 432 - 438.

Wangiyana, I. G. A. S., 2016. Molecular Phylogenetic Analyze of Fusarium from Agarwood and Others Fusarium with Different Type of Nutrition Based on Gen ITS 1. Jurnal Sangkareang Mataram. 2 (1), 1 - 5 .

Wangiyana, I G. A. S., 2015. Pemanfaatan Medium Alternatif untuk Pertumbuhan Isolat Fusarium sp. Penginduksi Pembentukan Gaharu pada Gyrinops versteegii (Gilg) Domke. Jurnal Sangkareang Mataram. 1 (3), 54 - 59.

Wei, Z., Bin, N., 2011. GC-MS analysis of the chemical components of the volatile oil from leaves of Aquilaria sinensis (Lour.) Gilg. Med. Plants. 2, 34 - 36 .

Xia, F., Sun, J., Jiang, Y., Tu, P., 2013. Further chemical investigation of leaves of Aquilaria sinensis. China J. Chin. Mater. Med. 39, 3299 - 3303.

Yang, M., Liang, Y., Chen, H., Huang, Y., Gong, H., 2014. Isolation and identification of the chemical constituent in ethyl acetate extracts of wild Aquilaria sinensis leaves. Modern Food Sci. Technol. 31, 128 - 163.

Yu, Q., Qi, J., Yu, H. X., Chen, L. L., Kou, J. P. , Liu, S. J., Yu, B. Y., 2013. Qualitative and quantitative analysis of phenolic compounds in the leaves of Aquilaria sinensis using liquid chromatography mass spectrometry. Phytochem. Anal. 24, 349 356.
Zhou, M., Wang, H., Kou, J., Yu, B., 2008. Antinocieptive and anti-inflammatory activities of Aquilaria sinensis (Lour.) Gilg. Leaves extract. J. Ethnopharmacol. 117, $345-350$.

Zulkifle, N. L. B., 2018. Antidiabetic Activity of Aquilaria malaccensis (Agarwood) Leaves Extracts. Thesis. Universiti Malaysia Pahang. 